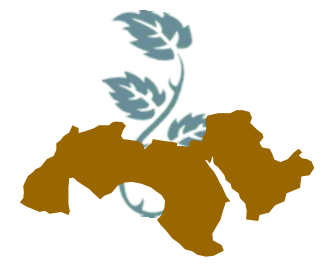

Arab Univ.

J. Agric. Sci., Ain Shams Univ., Cairo, 26(2), 529 - 538, 2018

\title{
USE OF CORN DISTILLERS DRIED GRAINS WITH SOLUBLES (DDGS) AND FOOTS IN NILE TILAPIA FINGERLINGS DIETS
}

\author{
Doaa, A.S. Fouda'; H.M. Khattab ${ }^{2}$; M.A. Amer ${ }^{2}$ and KH.F. El-Kholy ${ }^{1}$
}

[40]

\author{
1- Utilization By-Products Dept., Animal Production Research Institute, Agric., Research Center, \\ Dokki, Giza, Egypt \\ 2- Animal Production Dept., Fac. of Agric., Ain Shams Univ., Cairo, Egypt
}

Keywords: Nile tilapia, distillers dried grains with soluble, Foots, amino acids, fatty acids, digestibility, growth performance, feed efficiency

\section{ABSTRACT}

The aim of this study was to investigate the use of corn distillers dried grains with solubles (DDGS) (27.11\% CP) and Foots $(20.84 \% \mathrm{CP})$ as corn processing by-products in monosex Nile tilapia, Oreochromis niloticus diets to replace yellow corn as an energy source and its effect on growth performance, nutrients utilization, whole body proximate composition, nutrients digestibility and economic efficiency. Three hundreds and seventy five fingerlings of Nile tilapia (10 $0.05 \mathrm{~g}$ ) were randomly distributed into 15 circular plastic tanks $(1000 \mathrm{~L})$, representing 5 treatments. Isonitrogenous (25 to $25.84 \%$ ) and isocaloric (4174.79 to $4364.65 \mathrm{Kcal}$ $\mathrm{GE} / \mathrm{kg}$ ) experimental diets were prepared with substitution levels of DDGS $0 \%$ (T1), 20\% (T2) and $40 \%$ (T3) and Foots 20\% (T4) and 40\% (T5). The experimental period lasted for 18 week. Results showed that both of DDGS and Foots have higher in all measured amino acids content than those in yellow corn except cysteine. Moreover, DDGS and Foots have higher content of linoleic, oleic, stearic and palmitic acids than those in yellow corn. Also DDGS and Foots covered the nutrient requirements of the essential fatty acid linoleic $(18: 2 \omega 6)$ for Nile tilapia. Feed intake was significantly decreased as corn partially replaced by Foots more than the DDGS. Apparent digestibility coefficient of $\mathrm{CP}, \mathrm{EE}, \mathrm{NFE}$ and energy recorded the highest values for the T4 $(75.76,89.86 \%, 57.48$ and $68.71 \%$ ), respectively, followed by T3 with significant differences.
The increasing in substitution levels of yellow corn by DDGS did not significantly $(P>0.05)$ had an effect on Nile tilapia performances. However weight gain and specific growth rate SGR were gradually decreased with increasing the substitution levels of Foots. The CP content of Nile tilapia carcass was significantly increased with increasing the substitution levels of DDGS (T3) and Foots (T5). Feed conversion ratio (FCR) of the fish fed diets T4 (20\% Foots) was the best followed by T5 (40\% Foots). The cheaper feed cost gain was obtained from T5 (40\% Foots) followed by T4 $(20 \%$ Foots).

\section{INTRODUCTION}

The rapid expansion of the aquaculture industry, along with the improvement and change in aquaculture techniques, have increased the demand for fish feeds. Feed is the primary expense for tilapia production and protein is the most expensive component. Yellow corn has traditionally been used in fish feed as major source of dietary energy. However, when the production of yellow corn is decline and prices increase, fish nutritionists are considering less expensive plant protein and energy sources. By products obtained from food manufactories such as starch processing from yellow corn may be considered alternative energy source that can be used in fish feeds.

Corn dried distiller's grains with solubles (DDGS) are the predominant corn co-product produced by dry-grind fuel ethanol plants consisting of distiller's grains combined with the condensed solubles obtained after yeast fermentation to produce ethanol (Margareth et al 2013). Yellow corn contains about two-thirds starch and most of starch is 
converted to ethanol during fermentation, the nutrients (protein, fat, fiber, ash and phosphorus) content of DDGS are 2 to 3 times more concentrated than in corn. Thus, the chemical composition of DDGS varies with the source and quality of grain used to produce ethanol (Lim, and YildirimAksoy, 2008). Patil et al (2015) found that DM, CP, EE, CF, NFE, phosphorous and magnesium in corn DDGS were 89.7, 30.0, 9.8, 8.4, 47.2\%, $0.83 \%$ and $0.28 \%$ respectively. Schaeffer et al (2010) demonstrated that DDGS does not contain anti-nutritional factors (e.g. trypsine inhibitors or gossybol) that present in soybean meal and cottonseed meal. Foots are corn co-products when using corn grains to produce starch by wet milling process. The grain must be separated into its components including starch, fiber, gluten and germ, (by soaking in water). The germ is removed from the kernel then, corn oil is extracted from the germ. Finally, Foots are generated via the filtration of the extracted oil. Nutrients in Foots are concentrated compared with yellow corn. So the present experiment was conducted to study the effect of replacing yellow corn by $0,20,40 \%$ DDGS and 0 , $20,40 \%$ Foots in the diets of tilapia.

\section{MATERIALS AND METHODS}

This study was carried out at a commercial fish farm located in Kafr El-Shiekh Governorate, Egypt. Monosex Nile tilapia (Oeochromis niloticus) fingerlings of about $10 \pm 0.05 \mathrm{~g}$ were obtained from private farm in Fayoum Governorate, Egypt. Fish were acclimated to the farm conditions for two weeks. During this period the fish were fed the control diets. After the accumulation period, about 50 fish were randomly selected and their body weight were recorded, then they were stored as a zero group at $-40^{\circ} \mathrm{C}$ for proximate analysis. The adapted fish were transferred to circular plastic tanks (1000 L), 375 fingerling were randomly divided into five experimental groups. The experimental diets were fed to fish in fifteen tanks (three replicates) so each tank contained 25 fingerlings. After the feeding experiments had finished, the same fish in each tank were fed $2 \%$ of the total biomass. The method used to collect feces from the bottom of the tanks was siphoning. Feces were collected for two weeks. The experimental period lasted for 18 week.

The five experimental diets were almost isonitrogenous (25 to $25.84 \%$ crude protein) and isoenergetic ( 4442.34 to $4748.65 \mathrm{Kcal} \mathrm{GE} / \mathrm{kg}$ ). The percentage of yellow corn in the control diet was re- placed by 0,20 and $40 \%$ of DDGS T1, T2, T3 or 20 and $40 \%$ Foots (T4 and T5), respectively, as shown in Table (1).

\section{Growth performance}

Growth performance parameters were calculated according to the following equations:

- Average weight gain (Castell and Tiews 1980). AWG (g/fish) = [Average final weight $(g)$ Average initial weight $(\mathrm{g})]$

- Specific growth rate (Anderson et al 1984 and Tacon, 1987).

SGR $=$ [Ln final weight $(\mathrm{g})-\mathrm{Ln}$ initial weight $(\mathrm{g})]$ x 100 / experimental period (day).

- Feed conversion ratio (Tacon, 1987).

FCR $=[$ Feed intake, dry weight $(\mathrm{g}) /$ live weight gain $(\mathrm{g})$.

- Protein efficiency ratio (Hung et al. 1989).

PER = [Live weight gain (g) / protein intake (g)].

- Relative growth rate RGR (\%) = [Average final weight (g) / initial weight $(\mathrm{g})] \times 100$

- Protein productive value PPV $(\%)=[$ Final fish body protein $(\mathrm{g})$ - initial' fish body protein $(\mathrm{g}) /$ crude protein intake $(\mathrm{g})$ ] $\mathrm{x}$ 100

- Energy utilization

EU $(\%)=[$ Retained energy (kcal) /energy intake (kcal)] x 100

- Apparent digestibility coefficients (ADC \%) $=100-(100[\%$ Marker in feed $/ \%$ Marker in feces] $X$ [\% Nutrient in feces $/ \%$ Nutrient in feed])

The fish at the beginning of the experiments (zero time) and all samples of the fish from each tank at the end were separately punned in a mixer and dried at $65{ }^{\circ} \mathrm{C}$ overnight and were applied to the chemical analysis. Feed ingredients, experimental diets, fish carcass and fecal materials were analyzed chemically to estimate moisture, crude protein $(C P)$, ether extract $(E E)$, crude fiber (CF) and ash content according to the methods of A.O.A.C. (2012), while nitrogen free extract (NFE) was calculated by differences. Analysis of amino acids for yellow corn and the tested materials were done according to the methods of A.O.A.C. (2012). Determination of total fatty acids in yellow corn and the tested materials was done by Chromatography Knauar HPLC pump 64 UV. Detector column: UItracarb ODS (20) $250 \times 4.6 \mathrm{~mm}$. 

fingerlings diets

Table 1. The experimental diets formulation (\%) and chemical composition

\begin{tabular}{|l|c|c|c|c|c|}
\hline \multicolumn{1}{|c|}{ Ingredients } & T1 & T2 & T3 & T4 & T5 \\
\hline Yellow corn & 42.00 & 33.60 & 25.20 & 33.60 & 25.20 \\
DDGS & - & 8.40 & 16.80 & - & - \\
Foots & - & - & - & 8.40 & 16.80 \\
Soybean meal & 22.00 & 22.00 & 21.00 & 22.00 & 21.00 \\
Sunflower meal & 7.00 & 7.50 & 8.00 & 7.00 & 6.50 \\
Poultry by-products meal & 11.50 & 9.00 & 7.50 & 8.00 & 6.00 \\
Wheat bran & 16.00 & 18.00 & 20.00 & 19.50 & 23.00 \\
Vit. \& min. mix & 0.50 & 0.50 & 0.50 & 0.50 & 0.50 \\
Corn oil & 1.00 & 1.00 & 1.00 & 1.00 & 1.00 \\
Total & 100 & 100 & 100 & 100 & 100 \\
CP \% & 25.00 & 25.00 & 25.17 & 25.00 & 25.84 \\
CF \% & 5.84 & 6.62 & 7.41 & 7.74 & 9.60 \\
GE Kcal/kg & 4442.34 & 4454.98 & 4471.19 & 4587.57 & 4748.65 \\
\hline
\end{tabular}

*Each 1 kg contains: Vitamin A, 4.0 m.i.u; Vitamin $D_{3}, 0.8$ m.i.u; Vitamin E, 4.0g; vitamin K, 0.8 m.i.u; Vitamine K, 0.8g; Vitamine $B_{1}, 0.4 \mathrm{~g}$; Vitamine $B_{2}, 1.6 \mathrm{~g}$; Vitamine $B_{6}, 0.6 \mathrm{~g}$; Vitamine $B_{12}, 4.0 \mathrm{~g}$; Pantothenic acid, $4.0 \mathrm{~g}$; Nicotinic acid, $8.0 \mathrm{~g}$; Folic acid, 400.0mg; Biotine, 20.0g; Chlorine chloride, 200.0g; Copper, 4.0g; lodine, 4.0g, Iron, 12.0g, Zink, 22.0g and Selenium, $0.04 \mathrm{~g}$.

${ }^{* *} \mathrm{~T} 1=$ control, $\mathrm{T} 2=20 \%$ DDGS substituted by corn, T3=40\% DDGS substituted by corn, $\mathrm{T} 4=20 \%$ Foots substituted by corn and $\mathrm{T} 5=40 \%$ Foots substituted by corn.

Statistical analysis of the obtained data were analyzed using the SAS program (1999). Differences were considered significant according to Duncan (1955).

\section{RESULTS AND DISCUSSIONS}

\section{Water quality}

Results of water quality showed that dissolved oxygen ranged from 5.4 to $6.2 \mathrm{mg} / \mathrm{l}$, water temperature from 26 to $30 \stackrel{\circ}{\circ}, \mathrm{pH}$ from 7.0 to 7.5 , ammonia from 0.08 to $0.10 \mathrm{mg} / \mathrm{l}$, nitrite from 0.05 to 0.07 $\mathrm{mg} / \mathrm{l}$ and nitrate from 4.0 to $5.0 \mathrm{mg} / \mathrm{l}$. These values are laying with the normal values detected by Masser (1997); Redner and Stickney, (1979); Boyd (1990); Ross (2000); El-Sherif and El-Feky (2008) and Froese and Pauly (2011).

\section{Chemical composition of the tested materials}

Data of Table (2) clearly indicated that DDGS contain higher CP, NFE and ash than Foots. However, Foots contain higher EE, CF and GE than DDGS. Comparing the chemical composition of DDGS and Foots with yellow corn, crude protein, EE and GE contents in yellow corn represented $31 \%, 40 \%$ and $94 \%$ from those of DDGS content, respectively.

However, DDGS have higher contents of CP, EE, CF and GE than yellow corn. Also the same nutrients in yellow corn represented $40 \%$ (CP), $10 \%$ (EE) and $78 \%$ (GE) comparable to Foots. In this respect Lim and Yildirim (2008) reported that DDGS is a good source of energy and protein for various livestock animals.

\section{Amino acids and fatty acids composition}

The essential amino acids content (as percentage of DM) of DDGS and Foots compared to yellow corn are shown in Table (3). 
Table 2. Chemical composition (\%) of yellow corn, DDGS and Foots

\begin{tabular}{|l|c|c|c|c|c|c|c|}
\hline \multicolumn{1}{|c|}{ Ingredients } & DM & CP & EE & CF & NFE* & Ash & GE (Kcal/kg)** \\
\hline Yellow corn & 89.00 & 8.51 & 3.78 & 2.61 & 83.81 & 1.29 & 4294.82 \\
DDGS & 86.78 & 27.11 & 9.39 & 9.11 & 50.00 & 4.39 & 4783.41 \\
Foots & 82.56 & 20.84 & 36.21 & 22.98 & 18.49 & 1.48 & 6258.10 \\
\hline
\end{tabular}

* Calculated by differences.

** Calculated according to Jobling, (1983).

Table 3. Amino acids and fatty acids composition (\% DM) of the distiller's dried grains with solubles (DDGS), Foots and yellow corn

\begin{tabular}{|c|c|c|c|c|c|}
\hline \multicolumn{2}{|c|}{ Amino acids (\%) } & Yellow corn ${ }^{1}$ & DDGS $^{2}$ & Foots $^{2}$ & Tilapia Requirements ${ }^{3}$ \\
\hline \multicolumn{2}{|l|}{ Iso leucine } & 0.28 & 1.06 & 0.77 & 0.87 \\
\hline \multicolumn{2}{|l|}{ Leucine } & 0.95 & 2.76 & 1.62 & 0.95 \\
\hline \multicolumn{2}{|l|}{ Lysine } & 0.24 & 0.84 & 0.91 & 1.43 \\
\hline \multicolumn{2}{|l|}{ Phenylalanine } & 0.38 & 1.26 & 1.00 & 1.05 \\
\hline \multicolumn{2}{|l|}{ Tyrosine } & 0.06 & 1.15 & 0.80 & 0.28 \\
\hline \multicolumn{2}{|l|}{ Threonine } & 0.26 & 0.96 & 0.79 & 1.05 \\
\hline \multicolumn{2}{|l|}{ Valine } & 0.38 & 1.30 & 1.23 & 0.78 \\
\hline \multicolumn{2}{|l|}{ Cysteine } & 0.89 & 0.48 & 0.33 & 0.15 \\
\hline \multicolumn{2}{|l|}{ Methionine } & 0.21 & 0.52 & 0.35 & 0.75 \\
\hline \multicolumn{2}{|l|}{ Arginine } & 0.39 & 1.16 & 1.27 & 1.18 \\
\hline \multicolumn{2}{|l|}{ Histidine } & 0.23 & 0.68 & 0.65 & 0.48 \\
\hline \multicolumn{6}{|l|}{ Fatty acids (\%) } \\
\hline \multicolumn{2}{|l|}{ Palmitic acid } & 0.62 & 1.23 & 1.32 & \\
\hline Stearic acid & $(18: 0)$ & 0.10 & 0.21 & 0.19 & \\
\hline Oleic & $(18: 1) \omega 9$ & 1.17 & 3.51 & 2.69 & \\
\hline Linoleic & $(18: 2) \omega 6$ & 1.82 & 4.85 & 5.51 & \\
\hline Linolenice & $(18: 3) \omega 3$ & 0.09 & 0.07 & 0.06 & \\
\hline
\end{tabular}

1 Essential amino acid and fatty acids composition of yellow corn from Nutrient Requirements of Fish (NRC, 1993).

2 EAA and F.A of DDGS and Foots were analyzed in the Center laboratory of Food and Feed, in ARC.

${ }^{3}$ Tilapia requirements according to ((NRC, 1993). 
Tilapia require 10 essential amino acids in their diets for normal growth and metabolism. Specifically, fish have requirements for amino acids rather than crude protein (NRC 1993). Data of Table (3) showed that both of DDGS and Foots have higher in all measured amino acids content than those in yellow corn except cysteine. Lysine and methionine contents; are the most limiting amino acids required for fish and have highly figures compared to yellow corn (NRC 1993). However, the present results indicate that lysine and methionine contents of yellow corn represented $16 \%$ and $28 \%$ of tilapia requirements, respectively. Meanwhile, the essential amino acids, lysine and methionine represented (58 and $69 \%$ ) and ( 63 and $46 \%$ ) for DDGS and Foots of tilapia requirements, respectively. These results are in agreement with those obtained by Gaylord and Barrows (2009); Shelby et al 2008) and Kiron (2012).

Data of Table (3) showed that distillers dried grains with solubles (DDGS) and Foots have higher content of the all tested fatty acids than yellow corn specially the unsaturated fatty acids Linoleic acid and oleic acid. These results are in good agreement with those of Lim et al (2011) who showed that distillers dried grains with solubles (DDGS) owing to its high oil content, are rich in linoleic acid and are considered as an excellent source of energy and essential fatty acids for tilapia. The high ether extract content of Foots (36.21\%) lead to high content of fatty acids. Therein Foots showed higher content of linoleic acid and palmitic acids comparable to DDGS as shown in Table (3). Both of DDGS and Foots covered the nutrient requirements of the essential fatty acid linoleic $(18: 2 \omega 6)$ for Nile tilapia according to NRC 1993.

\section{Digestibility}

The apparent digestibility coefficients (ADC \%) of $\mathrm{CP}, \mathrm{EE}, \mathrm{NFE}$ and energy of T4 recorded the significant $(P<0.05)$ of highest values (75.76, $89.86 \%, 57.48$ and $68.71 \%$ ), respectively, followed by T3 with significant differences (Table 4). Whereas, the lowest digestibility coefficient values of CP, NFE and energy were obtained by T5 being $59.20,36.43$ and $52.60 \%$, respectively, the control diet has the lowest $(P<0.05)$ digestibility coefficient value of EE $(67.83 \%)$. The present results of the digestibility coefficient illustrate that increasing levels of DDGS instead of yellow corn owing to improve significantly $(P<0.05)$ the digestibility of all nutrients. Conversely, the increasing in substitution levels of Foots by yellow corn lead to significant $(P<0.05)$ decrease digestibility of $\mathrm{CP}, \mathrm{EE}, \mathrm{NFE}$ and energy comparing with the control diet. But the digestibility of EE was higher than the control. The decrease in CP digestibility of the diet T5 $(40 \%$ Foots) may be reflects the high fiber content (Table 1) of this diet (Sklan et al. 2004 and Anderson et al 1991).

Luiz, et al (2015) and Sklan et al (2004) recoded that apparent digestibility coefficient of energy was increased at high protein content of the diets and decreased with increasing crude fiber content. The crude fiber content showed a strong negative correlation with the ADCs of energy and nutrients in plant ingredients however, the $A D C$ of energy and $\mathrm{CP}$ were significantly higher $(P<0.05)$ in whole corn and corn gluten meal than in the other ingredients (corn germ meal and corn gluten feed).

\section{Growth performance parameters}

Growth performance parameters of Nile tilapia (O. niloticus) fed the experimental diets are presented in Table (5). Data showed non-significant decrease of feed intake, weight gain, FCR, PER, SGR and RGR as the level of DDGS was increased, while there were significant increase of PPV and EU. Also, non-significant decrease of feed intake and growth performance were observed as the level of Foots was increased, while FCR and PPV values were increased. The present results are in agreement with those obtained by Lim et al (2007); Labib et al (2010) and Suprayudi et al (2015) who reported that from the feed utilization results and economical point of view the diets contained $40 \%$ DDGS could be used in Nile tilapia diets.

Schaffer et al (2010) and Schaffer et al (2009) investigated the inclusion levels (17.5, 20, 22.5, 25 and $27.5 \%$ ) of DDGS with $5 \%$ fish meal for juvenile tilapia (Oreocromis niloticus). They indicated that 20\% DDGS achieved the highest apparent BWG among experimental diets, while $17.5 \%$ promoted the best feed conversion ratio (FCR) and PER. These results suggest that $20 \%$ DDGS can be included in tilapia diets containing $5 \%$ menhaden fish meal. The present results of the growth and feed efficiency parameters (FI, WG, FCR, SGR, RGR, PER, and EU \%) for the fish fed diet T4 were the best values and these results reflect the high digestibility coefficient of EE, NFE and energy for the diet T4 which replaced yellow corn by $40 \%$ Foots (Table 4 ). 
Table 4. Apparent digestibility coefficients (ADC \%) of nutrients

\begin{tabular}{|c|c|c|c|c|c|}
\hline Treatments & CP & EE & NFE & Energy & \\
\hline T1 & $63.47 \pm 0.16^{\mathrm{D}}$ & $67.83 \pm 0.30^{E}$ & $49.29 \pm 0.28^{\mathrm{D}}$ & $52.63 \pm 0.06$ & $\mathrm{D}$ \\
\hline T2 & $68.02 \pm 0.15^{c}$ & $68.14 \pm 0.14^{\mathrm{D}}$ & $48.05 \pm 0.07^{\mathrm{C}}$ & $56.90 \pm 0.18$ & c \\
\hline T3 & $74.50 \pm 0.24^{\text {B }}$ & $88.98 \pm 0.11^{B}$ & $54.35 \pm 0.16^{\mathrm{B}}$ & $65.16 \pm 0.42$ & B \\
\hline T4 & $75.76 \pm 0.06^{A}$ & $89.86 \pm 0.06^{A}$ & $57.84 \pm 0.07^{A}$ & $68.71 \pm 0.13$ & A \\
\hline T5 & $59.20 \pm 0.39^{E}$ & $78.58 \pm 0.09^{c}$ & $36.43 \pm 0.09^{E}$ & $52.60 \pm 0.19$ & E \\
\hline
\end{tabular}

A, B, C..etc: Means in the same column with different superscripts are significantly different $(P<0.05)$.

" T1=control, T2=20\% DDGS substituted by corn, T3=40\% DDGS substituted by corn, T4=20\% Foots substituted by corn and $\mathrm{T} 5=40 \%$ Foots substituted by corn.

Table 5. Feed intake, growth performance parameters, feed efficiency parameter and feed cost of Nile tilapia (Oreochromis niloticus) fingerling fed the experimental diets.

\begin{tabular}{|c|c|c|c|c|c|}
\hline Treatments & $\mathrm{T}_{1}$ & $\mathbf{T}_{2}$ & $T_{3}$ & $\mathrm{~T}_{4}$ & $\mathrm{~T}_{5}$ \\
\hline \multirow[t]{2}{*}{ FI g/fish } & A & A & A & $B$ & B \\
\hline & $150.66 \pm 2.29$ & $146.26 \pm 5.46$ & $140.49 \pm 2.76$ & $123.76 \pm 2.29$ & $122.81 \pm 0.20$ \\
\hline \multirow[t]{2}{*}{ WG g/fish } & A & $A B$ & $A B C$ & $\mathrm{BC}$ & $\mathrm{C}$ \\
\hline & $74.42 \pm 1.42$ & $72.33 \pm 2.77$ & $70.12 \pm 1.55$ & $67.86 \pm 0.82$ & $65.84 \pm 0.54$ \\
\hline \multirow[t]{2}{*}{ FCR } & A & A & A & B & B \\
\hline & $2.02 \pm 0.16$ & $2.02 \pm 0.00$ & $2.00 \pm 0.01$ & $1.82 \pm 0.01$ & $1.86 \pm 0.07$ \\
\hline \multirow[t]{2}{*}{ SGR \% } & A & $A B$ & $\mathrm{BC}$ & $\mathrm{BC}$ & $\mathrm{C}$ \\
\hline & $1.53 \pm 0.01$ & $1.51 \pm 0.01$ & $1.47 \pm 2.76$ & $1.48 \pm 0.00$ & $1.46 \pm 0.02$ \\
\hline \multirow[t]{2}{*}{ RGR \% } & A & $A B$ & $A B C$ & $\mathrm{BC}$ & C \\
\hline & $698.41 \pm 6.10$ & $670.09 \pm 8.93$ & $633.17 \pm 6.51$ & $642.14 \pm 4.31$ & $612.52 \pm 2.97$ \\
\hline \multirow[t]{2}{*}{ PER \% } & B & B & B & A & A \\
\hline & $1.97 \pm 0.47$ & $1.97 \pm 0.20$ & $1.99 \pm 0.15$ & $2.19 \pm 0.14$ & $2.14 \pm 0.19$ \\
\hline \multirow[t]{2}{*}{ PPV \% } & B & B & A & A & A \\
\hline & $20.49 \pm 0.50$ & $20.66 \pm 0.66$ & $23.38 \pm 0.18$ & $22.66 \pm 0.14$ & $23.49 \pm 0.21$ \\
\hline \multirow[t]{2}{*}{ EU \% } & B & $\mathrm{C}$ & B & A & A \\
\hline & $12.58 \pm 0.30$ & $11.76 \pm 0.01$ & $12.70 \pm 0.10$ & $13.34 \pm 0.08$ & $13.23 \pm 0.11$ \\
\hline Feed cost $\mathrm{Kg}$ gain & 6.14 & 6.02 & 5.36 & 5.13 & 4.81 \\
\hline
\end{tabular}

A, B, C..etc: Means in the same column with different superscripts are significantly different $(P<0.05)$.

* T1=control, T2=20\% DDGS substituted by corn, T3=40\% DDGS substituted by corn, T4=20\% Foots substituted by corn and $\mathrm{T} 5=40 \%$ Foots substituted by corn. 


\section{Carcass composition of fish}

The chemical composition of whole body parameters of Nile tilapia fingerlings fed diets contained 0,20 and 40\% DDGS or Foots as a partial replacement of yellow corn are summarized in Table (6).

The highest CP content (55.73\%) was detected in fish fed diet with $40 \%$ substitution of DDGS (T3) instead of yellow corn followed by T5 (54.93\%) and T2 (53.45\%), while, the lowest one was observed with fish feed the control diet $(50.21 \%)$. Increase the replacement level of DDGS instead of yellow corn $(20-40 \%)$ resulted significantly $(P<0.05)$ increase in fish body content of dry matter, crude protein, ether extract and energy content while, ash content was non-significant decreased. These results are in agreement with those obtained by Labib et al (2010). Also the increasing levels of Foots resulted significantly $(P<0.05)$ increase in $\mathrm{CP}$ and energy content, non-significant increase in $\mathrm{DM}$ and significant decrease in ash. Robinson, et al (2001) reported that the African catfish fed diet containing $50 \%$ corn gluten feed had a lower level of fillet fat than fish fed the control diet $(0 \%$ corn gluten feed) however, reduction in body fat of fish fed diets containing corn gluten feed may be due to the lower digestible energy or digestible energy to crude protein ratio in the diet. These results are in agreement with the present study, that showed significant carcass fat decrease of fish fed diets contains Foots compared to the control.

\section{Economic evaluation}

The results of Table (5) clearly indicated that replacing $40 \%$ yellow corn by Foots recorded the lowest feed cost/kg gain (4.81 L.E) while control showed the highest cost (6.14 L.E). The present results of the cost of diets contained $40 \%$ DDGS as a partial replacement of corn are in agreement with those obtained by Suprayudi et al (2015) and Labib et al (2010) who demonstrated that cost of feed per unit of Nile tilapia gain fed diet contain $40 \%$ DDGS was the most effective and economical more the control.

\section{Conclusion}

The present data concluded that $40 \%$ DDGS can be included in Nile tilapia diets as a replacement of yellow corn without any negative effects on body composition. Also, the results detected that Foots level up to $40 \%$ efficiently support an optimal growth and was economically effective for Nile tilapia fingerlings.

Table 6. Carcass composition of monosex Nile tilapia (Oreochromis niloticus) fingerlings

\begin{tabular}{|c|c|c|c|c|c|}
\hline Treatments* & DM \% & CP \% & EE \% & Ash \% & GE Kcal/kg \\
\hline & A & $\mathrm{F}$ & A & D & \\
\hline \multirow[t]{2}{*}{ T1 } & $20.71 \pm 0.04$ & $50.21 \pm 0.10$ & $16.90 \pm 0.04$ & $18.11 \pm 0.16$ & $5018.6 \pm 4.49$ \\
\hline & B & D & $\mathrm{E}$ & B & \\
\hline \multirow[t]{2}{*}{ T2 } & $20.16 \pm 0.01$ & $53.45 \pm 0.12$ & $14.00 \pm 0.07$ & $19.77 \pm 0.11$ & $4856.12 \pm 0.11$ \\
\hline & A & B & D & B & \\
\hline \multirow[t]{2}{*}{ T3 } & $20.66 \pm 0.11$ & $55.73 \pm 0.08$ & $15.70 \pm 0.07$ & $19.39 \pm 0.16$ & $4997.61 \pm 0.72$ \\
\hline & C & E & B & c & \\
\hline \multirow[t]{2}{*}{ T4 } & $19.77 \pm 0.12$ & $52.02 \pm 0.24$ & $16.61 \pm 0.05$ & $18.74 \pm 0.07$ & $5015.73 \pm 2.30$ \\
\hline & $\mathrm{BC}$ & $\mathrm{C}$ & $\mathrm{C}$ & $\mathrm{D}$ & \\
\hline T5 & $19.90 \pm 0.01$ & $54.93 \pm 0.04$ & $16.16 \pm 0.01$ & $17.79 \pm 0.06$ & $5066.82 \pm 7.05$ \\
\hline
\end{tabular}

A, B, C..etc: Means in the same column with different superscripts are significantly different $(P<0.05)$.

* $\mathrm{T} 1=$ control, T2=20\% DDGS substituted by corn, T3=40\% DDGS substituted by corn, T4=20\% Foots substituted by corn and $\mathrm{T} 5=40 \%$ Foots substituted by corn. 


\section{REFERENCES}

A.O.A.C. 2012. Association of Official Analytical Chemists International. Official Methods of Analysis, No. 994. 12, Chapter 4, pp. 18-19. $19^{\text {th }}$ ed. AOAC International, Gaithersburg, MD, USA.

Anderson, J., Capper, B.S. and Bromage, N.R. 1991. Measurement and predication of digestible energy values in feedstuffs for the herbivorous fish tilapia (Oreochromis niloticus). British Journal of Nutrition. 66, 37-48.

Anderson, J., Jackson, A.J., Matty, A.J. and Capper, B.S. 1984. Effects of dietary carbohydrate and fiber on the tilapia (Oreochromis niloticus, Linn). Aquaculture. 37, 303-314.

Boyd, C. E. 1990. Water quality in warm water fish pond. Aubum University, Alabama Agricultural Experiment Station. 482 p.

Castell, J.D. and Tiews, K. 1980. Report of the EIFAC, IUNS and ICES working group on the standardization of methodology in fish nutrient research. Hamburg, Fed. Rep. Germmany, 21 23 March 1979. EIFAC Tech. Pap., No. 36, 24 p.

Duncan, D. 1955. Multiple range tests and multiple $F$ tests. Biometrics. 11, 1-42.

El-Sherif, M.S. and EL-Feky, A.M. 2008. Effect of ammonia on Nile Tilapia (O. niloticus) performance and some hematological and histological measures. Eighth International Symposium on Tilapia in Aquaculture. Cairo, Egypt, pp. 1722.

Froese, R. and Pauly, D. 2011. The length weight relationship of fishes: a review. J. Applied Ichthyology. 22(4), 241-253.

Gaylord, T.G. and Barrows, F.T. 2009. Multiple amino acid supplementations to reduce dietary protein in plant-based rainbow trout Oncorhynchus mykiss feeds. Aquaculture. 287, 180184.

Hung, S.S.O., Fynn-Aikins, K.F., Lutes, P.B. and $\mathrm{Xu}, \mathbf{R} .1989$. Ability of juvenile white sturgeon (Acipenser transmonitaus) to utilize different carbohydrate sources. Journal Nutrition. 119, 727-733.

Jobling, M. 1983. A short review and critique of methodology used in fish growth and nutrition studies. Journal Fish Biology. 23, 685-703.

Kiron, V. 2012. Fish immune system and its nutritional modulation for preventive health care. Animal Feed Science and Technology. 173, 111-133.
Labib, E.M., Salama, F.A., Tonsy, H.D., Mahmoud, S.H. and Zaki, M.A. 2010. Nutritional studies on partial and total replacement of soybean meal by distillers dried grains with soluble (DDGS) in diets for Nile tilapia (Oreochromis niloticus). Egyptian Journal of Nutrition and Feeds. 13, 165-176.

Lim, C., Garcia, J.C., Yildirim-Aksoy, M., Klesius, P.H., Shoemaker, C.A. and Evans, J.J. 2007. Growth response and resistance to Streptococcus iniae of Nile tilapia, Oreochromis niloticus, fed diets containing distiller's dried grains with solubles. Journal of the World Aquaculture Society. 38, 231-237.

Lim, C., Li, E., Cai, C. and Klesius, P.K. 2011. Distiller's dried grains with solubles as an alternative protein source in diets of tilapia. Reviews in Aquaculture. 3, 172-178.

Lim, C. and Yildirim-Aksoy, M. 2008. Distillers dried grains with solubles as an alternative protein source in fish feeds. In proceedings of the $8^{\text {th }}$ International Symposium on Tilapia in Aquaculture, October 12-14, Cairo, Egypt. pp. 6782.

Luiz, V.O.V., Tadeu, T.O.X., Mariana, M., Luiz, E.P., Elias, N.M. and Wilson, M.F. 2015. Apparent Protein and Energy Digestibility and Amino Acid Availability of Corn and Coproducts in Extruded Diets for Nile Tilapia, Oreochromis niloticus. Journal of the World Aquaculture Society. 46(2), 183-190.

Margareth, Ø., Åshild, K., Gerald, S., Anders, S. and Vegard, D. 2013. Evaluation of distiller's dried grains with solubles (DDGS) and high protein distiller's dried grains (HPDDG) in diets for rainbow trout (Oncorhynchus mykiss). Aquaculture. 416, 201-208.

Masser, M.P. 1997. Cage culture (Site Selection and Water Quality). Southern Regional Aquaculture Center (SRAC Publication No. 161), the United States Dept. of Agriculture.

NRC. 1993. National Research Council Nutrient Requirements of Fish. National Academy Press, Washington, D.C., USA. pp. 67-68.

Patil, B.B., Dhage, S.A. and Pachpute, S.T. 2015. In vitro evaluation of different distiller's grains with solubles. Indian Journal of Animal Nutrition. 32,181-186.

Redner, B.D. and Stickney, R.R. 1979. Acclimation to ammonia by Tilapia aurea. Trans. Am. Fish. Soc., 108, 383 - 388.

Robinson, E.H., Li, M.H. and Bruce, B.M. 2001. Evaluation of Corn Gluten Feed as a Dietary 

fingerlings diets

Ingredient for Pond-Raised Channel Catfish Zctulurus punctatus. J. of the World Aquaculture Society. 32(1), 68-71.

Ross, L.G. 2000. Environmental physiology and energetics. pp. 89-128. In: M.C.M. Beveridge and B.J. McAndrew (eds.) Tilapias: Biology and Exploitation, Fish and Fisheries Series 25, Kluwer Academic Publishers, Dordrecht, the Netherlands.

SAS 1999. Statistical Analysis System, SAS/STAT User's Guide. Release 6.03 Edn. SAS Institute, Cary, NC, 1028 p.

Schaffer, T.W., Brown, M.I. and Rosentrater, K.A. 2009. Performance characteristics of Nile tilapia (Oreochromis niloticus) fed diets containing graded levels of fuel-based distiller's dried grains with solubles. J. of Aquaculture Feed and Nutrition. 1, 78-83.

Schaffer, T.W., Brown, M.L., Rosentrater, K.A. and Muthukumarappan, K. 2010. Utilization of diets containing grade levels of ethanol production co-products by Nile tilapia. J. of Animal Physiology and Animal Nutrition. 94, 348354.
Shelby, R.A., Lim, C., Yildirim-Aksoy, M. and Klesius, P.H. 2008. Effect of distillers dried grains with solubles incorporated-diets on growth and immune function and disease resistance of Nile tilapia, Oreochromis niloticus. Aquaculture Research. 39, 1351-1353.

Sklan, D., Prag, T. and Lupatsch, I. 2004. Apparent digestibility coefficient of feed ingredients and their prediction in diets for tilapia Oreochromis niloticus $\times$ Oreochromis aureus (Teleostei, Cichlidae). Aquaculture Research. 35, 358-364.

Suprayudi, M.A., Yaniharto, D., Priyoutomo, N., Kurnianto, A., Ekasari, J., Dedijusadi and Haga, Y. 2015. Evaluation of practical diets containing high levels of corn distiller's dried grains with solubles on Red tilapia floating net cage production performance. Pakistan J. of Nutrition. 14, 708-711.

Tacon, A.G.J. 1987. The nutrition and feeding of farmed fish and shrimp: a- Traning Manuanl. 1The essential nutrients. FAO, Brasilia, Brazil. GCP/RLA/075/ITA Field Document 2/E, 117 p. 